\title{
Fixing of Warming of Climate in Ring Chronologies of Shrubs in the North of Yamal and Gyda Peninsula
}

\author{
Stanislav P. Arefyev* \\ Institute of Northern Development $S B R A S$ \\ Box 2774, Tyumen-3, 625003, Russia
}

Received 27.04.2015, received in revised form 16.06.2015, accepted 20.09.2015

The tree ring chronology (TRC) of a gray willow (Salix glauca) growing on a northern limit of the distribution on the Yamal Peninsula (the lake Langatibeyto, 71 ${ }^{\circ} 04^{\prime} 35^{\prime \prime} \mathrm{N}, 70^{\circ} 22^{\prime} 09^{\prime \prime}$ E) and Gyda

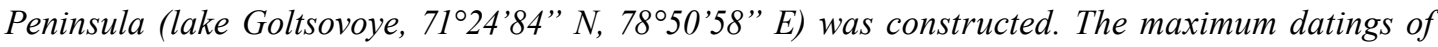
shrubs correspond to 1965 and 1954. It was also constructed the integrated century (1874-2011) TRC of the shrubs of Northern Yamal - a gray willow, shaggy willow (Salix lanata), a dwarfish birch (Betula nana), which includes TRC of both Langatibeyto's point and the territory of the Bovanenkovskoe gas-condensate field $\left(70^{\circ} 21^{\prime} 45^{\prime \prime} \mathrm{N}, 68^{\circ} 26^{\prime} 49^{\prime \prime}\right.$ E). Owing to biological features of growth of tundra shrubs the chronologies of absolute width of their rings show good compliance with the general trend of climate warming of the region in XX-the beginning of the XXI centuries. The compliance isn't traced if indexation is used, for example, by the method of negative exponential smoothing because it demands the larger extent of chronologies. The greatest response of an absolute radial gain of shrubs is noted on the air temperature of summer months of the current year, first of all July (on Gyda), and also June (on Yamal). Correlation of TRC with summer air temperatures of the nearby meteorological stations (Antipayuta on Gyda Peninsula, Kharasavey on Yamal) reaches $+0,72$. Correlation of TRC of Northern Yamal with summer temperatures of Salekhard makes 0,65-0,68 that allows to use widely its long set of meteodata (since 1882) on Yamal, and to use a meteodata of Dickson (since 1916) on Gyda. A response of the studied TRC to the spring air temperatures making the greatest contribution to the warming of climate of the region is low and in general negative (correlation coefficient is about-0,3), a response to the previous winter temperatures is low and in general positive (about 0,3). On Yamal in comparison with Gyda the curve of responses to monthly air temperatures is displaced for earlier calendar terms. Determination of parameters of multiple regression of TRC of Northern Yamal on average monthly air temperatures of Salekhard and Marre-Sale using models with different number of the months-predictors showed high (0,7-0,9) and significant by all criteria correlation, both for training, and for control part of chronology. It is indicative that the high correlation is found in models of regression of TRC on three months of the summer season $(0,74-0,78)$ which is on the second place

(C) Siberian Federal University. All rights reserved

* Corresponding author E-mail address: sp_arefyev@mail.ru 
on a contribution to warming of climate of the region after the spring period. The similar picture is shown by TRC of an shrubby alder (Duschekia fruticosa) and a shaggy willow from a northern limit of a zone of the shrubby tundra of Yamal (68'29'41 “ $N, 72^{\circ} 27^{\prime} 10^{\circ}$ " E) where the century trend of increase in width of rings is more, but multiple correlation with temperatures of summer months is slightly weaker $(0,63-0,68)$.

Keywords: climate changes, average monthly air temperatures, dendrochronological reconstruction, tundra shrubs, Arctic and Subarctic, Western Siberia, gas-condensate fields.

\title{
Фиксация потепления климата \\ в древесно-кольцевых хронологиях кустарников на севере Ямала и Гыданского полуострова
}

\author{
С.П. Арефьев \\ Институт проблем освоения Севера СО РАН \\ Россия, 625003, Тюмень-3, а/я 2774
}

Построены древесно-кольщевые хронологии (ДКХ) ивы сизой (Salix glauca), произрастающей на северном пределе своего распространения на полуострове Ямал (оз. Лангатибейто,

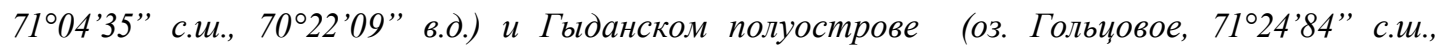
7850'58” в.д.) при максимальных датировках кустарников, соответственно, с 1965 и с 1954 г2. Построена также объединенная вековая (1874-2011) ДКХ кустарников Северного Ямала - ивы сизой, ивы мохнатой (Salix lanata), березы карликовой (Betula nana), включающая ДКХ и из пункта Лангатибейто и с территории Бованенковского газоконденсатного месторождения (БГКМ) (70²1'45” с.и., 68²6'49” в.д.). В силу биологических особенностей роста тундровых кустарников абсолютные хронологии ширины их годичных колеи показали хорошее соответствие общему тренду потепления климата региона в XX-начале ХХІ столетия, что не прослеживается при индексации, например, методом отрицательного экспоненциального сглаживания, требуюшим большей протяженности хронологий. Наибольший отклик абсолютного радиального прироста кустарников отмечен на температуру воздуха летних месящев текущего года, прежде всего июля (на Гыдане), а также июня (на Ямале). Корреляция ДКХ с летними температурами воздуха ближайших метеостанщий (Антипаюта на Гыдане, Харасавэй на Ямале) достигает +0,72. Коррелячия ДКХ Северного Ямала с летними температурами Салехарда составляет 0,65-0,68, что позволяет широко использовать на Ямале его продолжстельный метеоряд (с 1882 2.), а на Гыдане -метеоряд Диксона (с 1916 г.). Отклик исследованных ДКХ на весенние температуры воздуха, вносящие наибольший вклад в потепление климата региона, низкий и в иелом отрицательный (корреляция-0,3), отклик на температуры предыдущей зимы - низкий и 
в целом положительный $(0,3)$. На Ямале по сравнению с Гыданом кривая откликов на месячные температуры воздуха смещена на более ранние календарные сроки. Определение параметров многофакторной регрессии ДКХ Северного Ямала по среднемесячным температурам воздуха Салехарда и Марре-Сале на моделях с разным числом месячев-предикторов показало высокую (0,7-0,9) и значимую по всем критериям корреляцию как для обучающей, так и для контрольной части хронологии. Показательна высокая корреляция в моделях регрессии ДКХ по трем месяцам летнего сезона (0,74-0,78), стоящего на втором месте по вкладу в потепление климата региона после весеннего периода. Аналогичную картину демонстрируют ДКХ по ольхе кустарниковой - Duschekia fruticosa и иве мохнатой с северного предела зонь кустарниковьх тундр Ямала (68²9’41” с.и., 72²7’10” в.д.), где вековой тренд увеличения ииринь колец больше, но множественная корреляции с температурами летних месяцев несколько слабее $(0,63-0,68)$.

Ключевые слова: изменения климата, среднемесячные температуры воздуха, дендрохронологические реконструкиии, тундровые кустарники, Арктика и Субарктика, Западная Сибирь, газоконденсатные месторождения.

\section{Введение}

Общая тенденция потепления климата в Ямало-Гыданском секторе Арктики и Субарктики в течение XX - начала XXI столетия не вызывает сомнений (Булыгина и др., 2010), поскольку подтверждается данными инструментальных наблюдений, ведущихся, в частности, в Салехарде с 1882 г., на Диксоне с 1916 г. И хотя максимальный возраст тундровых кустарников соответствует приблизительно этим же срокам, в последние годы отмечается возрастающий интерес к исследованию их древесно-кольцевых хронологий (ДКХ) (Schweingruber, Pschlod, 2005; Schweingruber, Rump, 2010; Linderholm et al., 2010; Buchwal et al., 2013; Buchwal, 2014). Прежде всего, они позволяют провести дендроклиматические реконструкции в районах Арктики (Шпицберген, Гренландия и др.), находящихся на многие сотни километров севернее границы распространения деревьев и не всегда обеспеченных столь длительными рядами инструментальных наблюдений климата. Не менее важно и то, что ДКХ кустарников дают возможность исследовать реакцию биоты (на базовом уровне продуцентов) на происходящие в Арктике климатические подвижки. Проведенными исследованиями, в частности, выявлена тесная достоверная связь радиального и верхушечного прироста арктических кустарников не только с летними (особенно июльскими), но в ряде случаев и с зимними (декабрь, январь) температурами воздуха, а также с весенней температурой почвы (Alsos at al., 2012; Buchwal et al., 2013; Buchwal, 2014). На Ямале исследована и реакция ивы на оползневые явления (Лейбман и др., 2000; Николаев, Самсонова, 2012), кустарники использованы даже в археологической датировке (Шиятов, Хантемиров, 2000). Однако построенные ДКХ пока не дают оснований судить о вековых климатических тенденциях, хотя об этом свидетельствует прогрессирующее распространение кустарниковой растительности в высокие широты Арктики (Myers-Smith et al., 2011; Rundqvist et al., 2011), подобное продвижению северной и высотной границы деревьев в Ямальском секторе Субарктики, описанное С.Г. Шиятовым (2009). 
Нами исследования ДКХ тундровых кустарников Ямало-Гыданского региона велись с начала 1990-х гг. (Арефьев, 1994, 1998, 2003, 2006, 2010; Природная среда Ямала, 1995, 2000). Охвачены зоны лесотундры, кустарниковых и типичных тундр вплоть до северной части последних на территории Бованенковского газоконденсатного месторождения (БГКМ), построены ДКХ ивы мохнатой - Salix lanata L. (c 1908 г.), березы карликовой - Betula nana L. (с 1874 г.), ольхи кустарниковой - Duschekia fruticosa (Rupr.) Pouzar (с 1852 г.). Отмечено увеличение прироста кустарников в ХХ столетии, особенно на юге тундровой зоны и в районах освоения
Субарктики. Целью настоящей работы является исследование самых северных для региона ДКХ по тундровым кустарникам, обнаруженным на полуострове Ямал и Гыданском полуострове.

\section{Материалы и методы}

Границы широтных зон и подзон ЯмалоГыданской области (Ямало-Гыданская область, 1977) во многом совпадают с северным пределом распространения тех или иных видов древесных растений (рис. 1). Это очевидно для лесотундры. Зона кустарниковых тундр ограничена на севере распространением ольхи кустарниковой, зона типичных

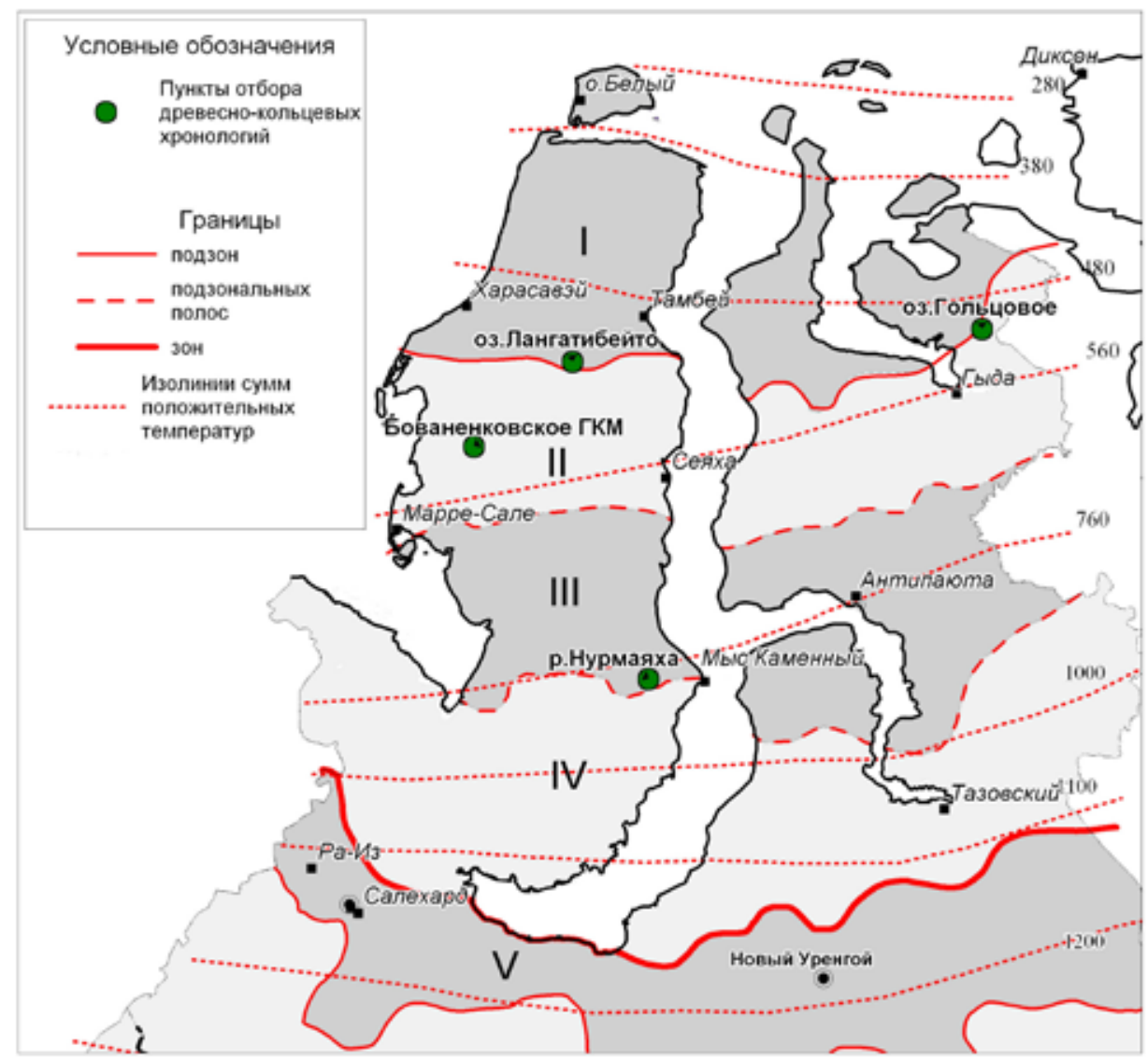

Рис. 1. Схема района исследований (по: Растительность..., 1976): I - арктическая тундра; II - северная полоса субарктических типичных тундр; III - южная полоса субарктических типичных тундр; IV субарктические кустарниковые тундры; V - лесотундра 
тундр - распространением березы карликовой и ив мохнатой и сизой (Salix glauca L.). Редкие фрагменты зональной кустарниковой растительности добираются до более северных зон, нередко достигая там и максимального возраста. Наиболее глубоко на север способна проникать ива сизая, занимая там наиболее дренированные участки (подобно иве мохнатой в зоне типичных тундр), в то время как южнее в основной части ареала она обычно образует тонкие короткоживущие побеги в заболоченных местообитаниях.

Ход среднегодовых температур воздуха в XX - начале XXI столетия довольно сходен по всему региону. Так, корреляция самой длительной хронологии наблюдений температуры воздуха по данным метеостанции (м/с) Салехард (зона лесотундры) с хронологиями зоны типичных тундр, удаленной от нее на 300-400 км (м/с Антипаюта и Марре-Сале), составляет 0,91-0,93 и даже с хронологиями островов арктической тундры, находящихся на расстоянии 700-800 км (о. Белый, о. Диксон), она не меньше 0,75-0,78. Несколько ниже сходство хронологий сезонных температур воздуха, например летних, соответственно 0,78-0,85 и 0,53-0,68, еще ниже - среднемесячных, в частности июльских: $0,70-0,85$ и $0,34-$ 0,57 . Хотя сходство уменьшается в северовосточном направлении, данные м/с Салехард и Диксон могут широко использоваться в региональной дендроклиматологии. Остальные метеостанции региона имеют более короткий срок наблюдений (с 1940-1950 гг.).

При несомненном общем потеплении климата региона оно определяется, прежде всего, весенними и в меньшей степени летними температурами воздуха, осенние и зимние почти лишены линейного тренда на вековом фоне. Так, по Салехарду за период 1883-2012 гг. увеличение сезонных температур в расчете на 100 лет составило соот- ветственно 2,$1 ; 1,2 ; 0,8$ и $0,5^{\circ} \mathrm{C}$. Наибольший рост летних температур наблюдался в период с 1960-х гг. по настоящее время: около $3,4{ }^{\circ} \mathrm{C}$ в расчете на 100 лет по большинству метеостанций региона.

Потепление в регионе происходит, как правило, на фоне уменьшения летнего количества осадков (за исключением, например, м/с Марре-Сале и Тазовский), при этом количество осадков в другие сезоны на вековом фоне изменяется слабее, чаще в сторону увеличения, что в целом усиливает континентальность климата в период вегетации кустарников.

Материал для исследования ивы сизой был любезно отобран в середине августа 2011 г. С.Н. Гашевым из двух пунктов: близ оз. Лангатибейто (Ямал, $71^{\circ} 04^{\prime} 35^{\prime \prime}$ с.ш., $70^{\circ} 22^{\prime} 09^{\prime \prime}$ в.д.) и близ оз. Гольцового (восточнее пос. Гыда, 71²4’84” с.ш., 7850’58” в.д.). В каждом из них (а местопроизрастания кустарников на границе арктической тундры крайне редки и представлены малым числом стволов) взято по 11 образцов длиной 15-20 см, срезанных у основания стволика. В силу большой изменчивости ширины колец на каждом образце исследован нижний и верхний срезы, на каждом срезе кольца измеряли по четырем перпендикулярным радиусам с помощью бинокулярного микроскопа (увеличение $8 \times 7$ ). В случае непригодности части радиусов для измерений число измеренных радиусов сокращалось до 2-3, иногда до 1 на срез. Всего по пункту Лангатибейто измерено 63 радиуса, по пункту Гольцовое - 52. В работе также использованы ранее опубликованные (Арефьев, 2000) более продолжительные векового масштаба ДКХ с территории Бованенковского ГКМ, расположенного в 100 км юго-западнее оз. Лангатибейто в подзоне типичных тундр и ДКХ из низовьев р. Нурмаяха на северном пределе 
поздоны кустарниковых тундр. Для измерения образцов ивы мохнатой и березы карликовой, использованных для составления этих ДКХ, применяли методику, описанную выше. У ольхи кустарниковой из каждого стволика брали один керновый образец и измеряли его по двум радиусам, что объясняется малочисленностью ольхи в крайнем северном ее местонахождении, а также характерной для нее меньшей изменчивостью ширины годичного кольца. Таким образом, ДКХ с Бованенковского ГКМ обеспечены 68 радиусами березы карликовой и 64 - ивы мохнатой, ДКХ из низовьев Нурмаяхи - 40 радиусами ивы мохнатой и 12 - ольхи кустарниковой.

В ходе перекрестной датировки с учетом особенностей радиального роста стелящихся кустарников (Methods of dendrochronology, 1990; Schweingruber, Rump, 2010) с использованием ранее построенных ДКХ из ближайших пунктов составлены абсолютные хронологии по отдельным радиусам, обобщенные затем простым суммированием по каждому пункту. Для дальнейших расчетов применяли часть обобщенной хронологии, представленную не менее чем 10 радиусами (рис. 2). При этом и недостаточно репрезентативная часть обобщенных ДКХ, обычно содержащая наи- более старые кольца, несущие уникальную информацию (в частности, в случае с ольхой), не исключалась нами из анализа полностью, а рассматривалась в качестве возможного дополнительного аргумента, нередко весьма иллюстративно подтверждающего единую для разных хронологий закономерность.

Индексация ширины колец проведена методом отрицательного экспоненциального сглаживания отдельно для каждого радиуса с дальнейшим обобщением (Methods of dendrochronology, 1990; Gopalan, 2000). Этим методом, широко известным в качестве одного из лучших в дендроклиматологии, выявлен хороший уровень корреляции ДКХ ив Бованенковского ГКМ с июльской температурой воздуха - до 0,68 (Николаев, Самсонова, 2012), но он недостаточно пригоден для выявления трендов, по своим масштабам близких к продолжительности самой хронологии, поэтому использован только для сопоставления с данными анализа неиндексированных кустарниковых ДКХ. Для исследования дендроклиматических закономерностей рассчитаны параметры множественной регрессии обобщенных рядов по среднемесячным температурам воздуха и суммам осадков с применением пакетов STATISTICA и EXCEL. Использованы

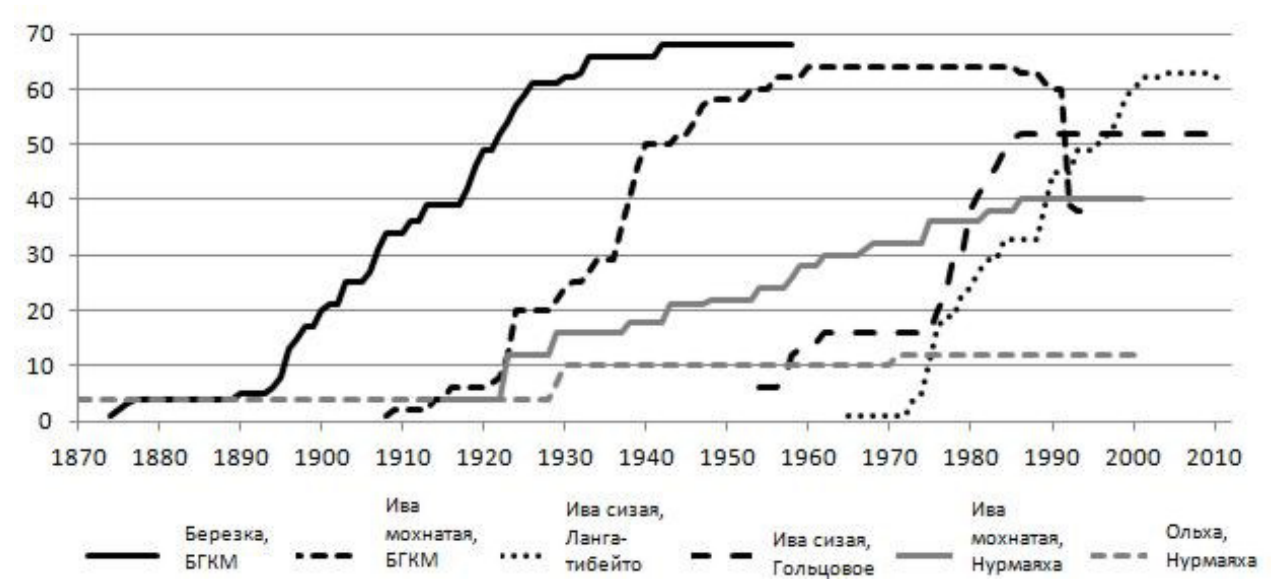

Рис. 2. Число радиусов в обобщенных древесно-кольцевых хронологиях 
метеоданные ресурсов http://Aisori.meteo.ru/ ClimateR и http://www.atlas-yakutia.ru.

\section{Результаты и обсуждение}

Начало наиболее протяженных индивидуальных ДКХ из пос. Гольцовое пришлось на 1954 г. (58 лет), а из пос. Лангатибейто - на 1965 г. (47 лет), репрезентативная часть этих ДКХ при обобщении простирается, соответственно, с 1958 и 1975 г. При значительной разности формы хронологических кривых отдельных радиусов в обобщенных абсолютных хронологиях «кривая большого роста» практически не прослеживается (рис. 3, 4), их автокорреляция первого порядка низкая (соответственно 0,00 и 0,25 ) и не превышает автокорреляцию рядов июльских и летних температур региона на этих временных промежутках. Выпадающие кольца выявлены как в начале, так и в конце роста, большинство из них приходится на 1966-1974, 1980, 1997, 2001, 2005, 2010 гг. Инициированное в год с небла-

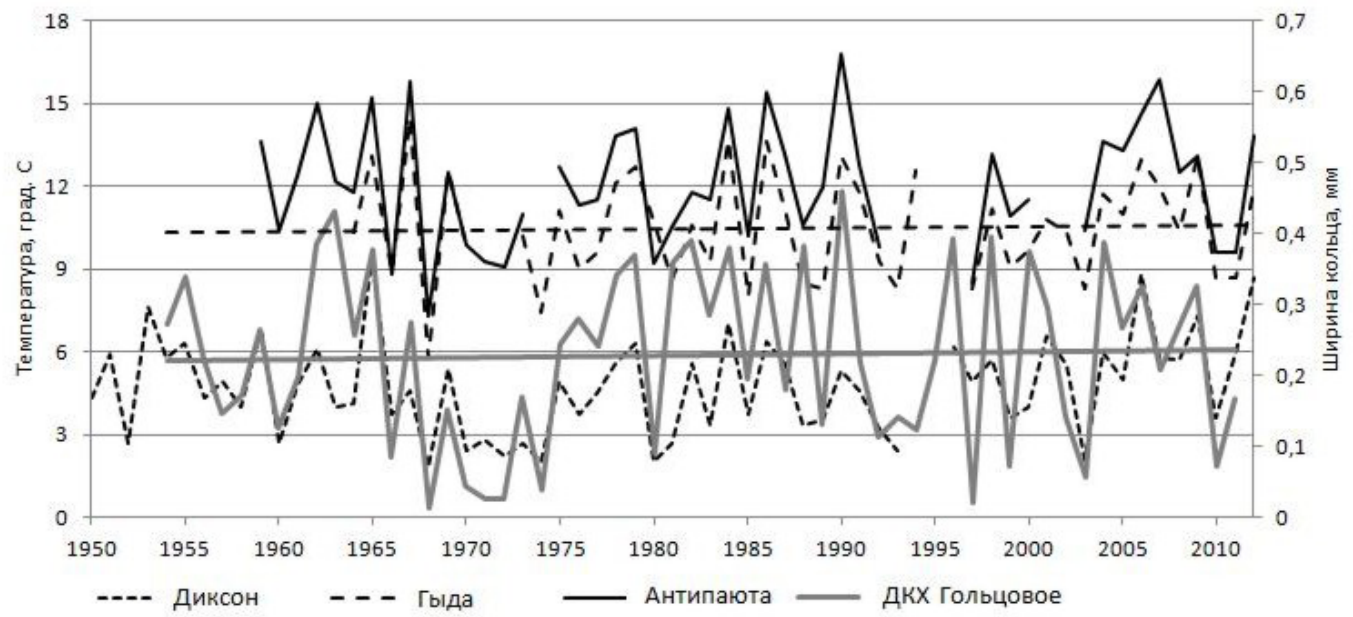

Рис. 3. Хронологии ширины колец ивы сизой из пос. Гольцовое (Гыданский полуостров) и июльских температур воздуха по данным ближайших метеостанций (с линейными трендами)

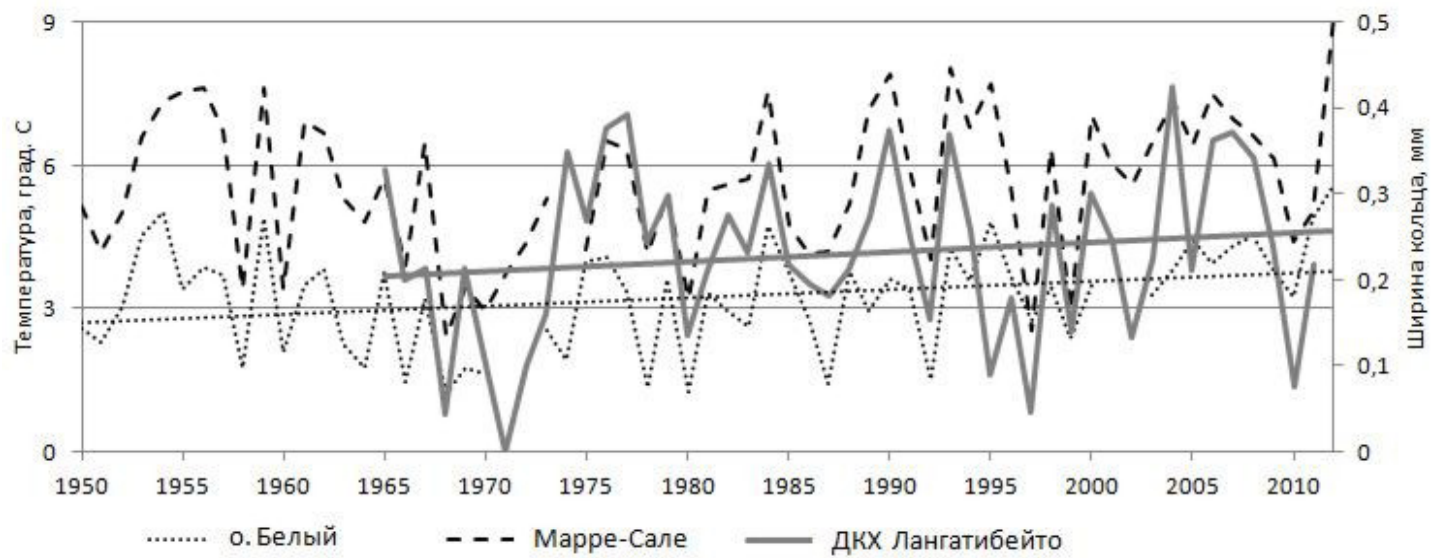

Рис. 4. Хронологии ширины колец ивы сизой из пос. Лангатибейто (Ямал) и летних (июль - август) температур воздуха по данным ближайших метеостанций (с линейными трендами) 
гоприятными условиями прекращение камбиальной активности на отдельных радиусах продолжается иногда до 3-4 лет кряду. Доля выпавших колец в гыданской хронологии составила 10,2 \%, в ямальской - 7,4 \%. Корреляция между хронологиями 0,59.

На рис. 3 и 4 хорошо видна синхронность абсолютного радиального прироста кустарников из пунктов Гольцовое и Лангатибейто с многолетним ходом июльских и летних (июль - август) температур воздуха по данным метеостанций, соответственно, восточной и западной части рассматриваемого региона. Линейные тренды кустарниковых хронологий вполне отражают упомянутые выше положительные многолетние тренды температур в регионе. Для обеих абсолютных ДКХ определен значительный уровень корреляции с июльскими и летними температурами метеостанций региона: от 0,4 для наиболее удаленных до 0,7 для ближайших, что не уступает упомянутому выше отклику индексированных кустарниковых хронологий БГКМ (Николаев, Самсонова, 2012).

ДКХ из пос. Гольцовое обнаруживает наибольшую корреляцию с июльскими температурами воздуха м/с Антипаюта $(0,72)$. Даже с температурными данным м/с Диксон, расположенной на северо-востоке региона, такая корреляция составляет 0,62, а с данными м/с Тазовский, находящейся на юго-востоке, 0,56. При этом с температурными данными м/с Гыда, находящейся в непосредственной близости к пос. Гольцовое, корреляция ниже $(0,58)$. Можно предположить невысокое качество наблюдений м/с Гыда. Вместе с тем температуры всего летнего сезона, регистрируемые на м/с Гыда (как и на м/с Антипаюта), максимально коррелируют с рассматриваемой ДКХ (0,66-0,67).

ДКХ из пункта Лангатибейто обнаруживает наибольшую корреляцию с июльски- ми температурами, зарегистрированными на ближайших ямальских метеостанциях: Харасавэй-Моржовая $(0,71)$ и Тамбей $(0,70)$, немного ниже - с данными ближайших с юга м/с Марре-Сале $(0,67)$ и Сёяха $(0,66)$, причем довольно высокая корреляция сохраняется для метеостанций южной части полуострова Ямал вплоть до м/с Салехард $(0,65)$, а по м/с Ра-Из (на Полярном Урале) она достигает 0,71; с температурными данными, полученными на самой северной метеостанции на о-ве Белом, она существенно ниже $(0,54)$. Для корреляции этой ДКХ с летними температурами прослеживается аналогичная картина при наибольших значениях для м/с Марре-Сале $(0,72)$ и Сёяха $(0,68)$ и довольно высоком значении для м/с Салехард на юго-западе $(0,63)$.

Изучение отклика рассматриваемых кустарниковых ДКХ на 2-летний спектр среднемесячных температур воздуха, оцененного парным коэффициентом корреляции $r$, показало определенные закономерности (рис. 5). Наиболее существенные $(0,4-0,7)$ положительные корреляции прироста, как уже говорилось, отмечены для летних месяцев, прежде всего для июля, причем июньские температуры на Ямале (Лангатибейто) в этом плане мало уступают июльским, а на Гыдане (Гольцовое) корреляция с ними низкая $(0,2)$. Корреляция с августовскими температурами на Гыдане также заметно ниже.

Весенние температуры воздуха вносят наибольший вклад в потепление климата региона. При этом отклик прироста кустарников на весенние температуры текущего года на Гыдане хотя и слабый, но устойчиво отрицательный, что, очевидно, связано с физиологической засухой в условиях повышения солнечной инсоляции и относительно низкого снегового покрова в восточной части региона (рис. 6). На Ямале (Лангатибейто), где снега выпадает больше, это менее выражено, а для 
А. Гольцовое (Гыданский полуостров)

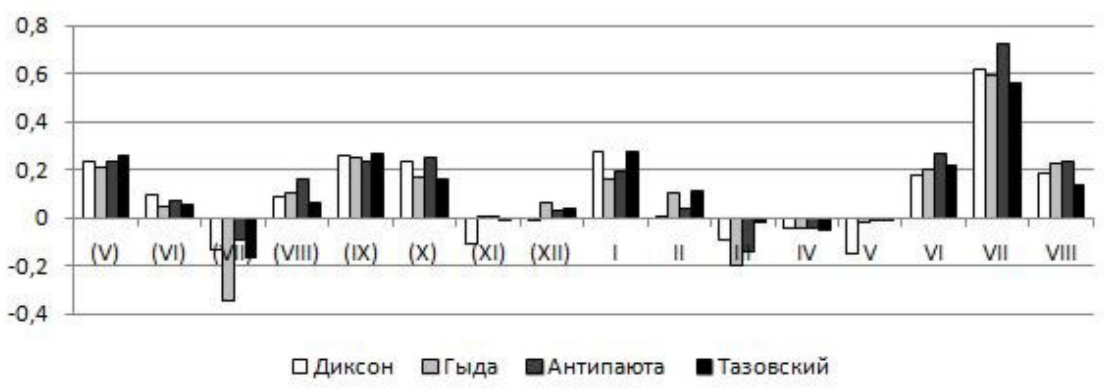

Б. Лангатибейто (Ямал)

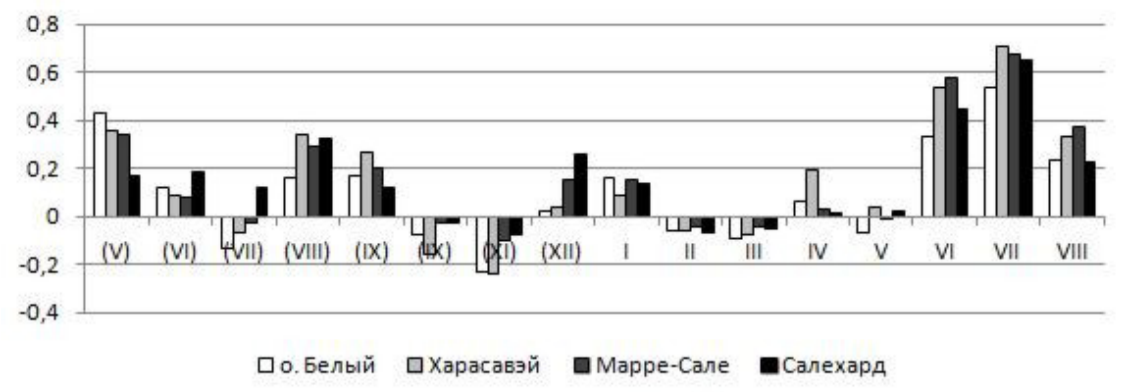

В. Объединенная ДКХ: БГКМ и Лангатибейто (Северный Ямал)

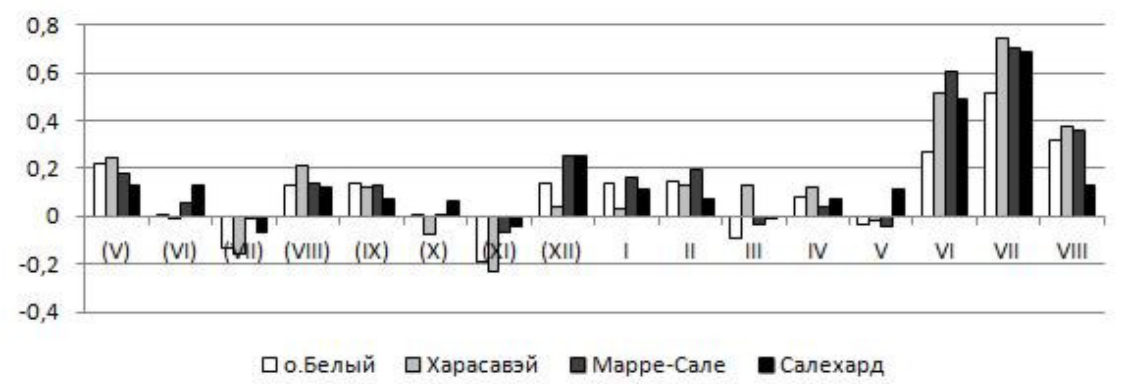

Рис. 5. Отклики (парный коэффициент корреляции) ДКХ кустарников из разных пунктов ЯмалоГыданского региона на среднемесячные температуры воздуха предыдущего и текущего года по данным ближайших метеостанций

апреля, когда уровень снега достигает максимума, отмечается даже небольшая положительная корреляция прироста с температурой воздуха.

Отклик прироста на зимние температуры текущего года на Гыдане положительный, особенно в январе, что, очевидно, связано с неблагоприятным влиянием на кустарники наиболее низких температур, характерных для восточной части региона. Западнее на Ямале (Лангатибейто) зимы несколько мягче, вероятно, поэтому положительный температурный отклик отмечен только для первых зимних месяцев, когда защитный снежный покров еще невелик.

Отклик прироста кустарников на августовские и осенние температуры предыдущего года сначала положительный, затем отрицательный (особенно на Ямале), возможно, вследствие нарушения адаптаций кустарников к зиме в условиях продолжительного осеннего тепла. 


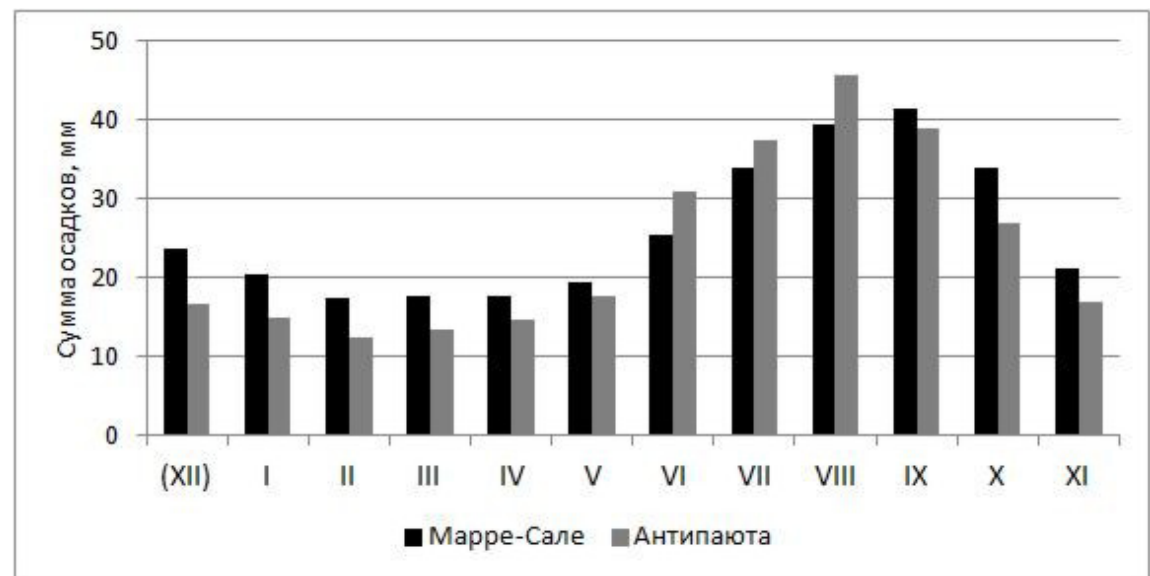

Рис. 6. Среднемесячное количество осадков в западной (данные метеостанции Марре-Сале) и восточной (метеостанция Антипаюта) частях Ямало-Гыданского региона

Отрицательный отклик прироста на июльские температуры предыдущего года обусловлен, вероятно, внутренней скоррелированностью хронологий на фоне высокого отклика на июльские температуры текущего года. Повышенный положительный отклик $(0,3-0,4)$ отмечен на майские температуры предыдущего года.

Анализ климатических откликов более продолжительной объединенной ДКХ по Северному Ямалу (Бованенковское ГКМ и Лангатибейто), о которой речь пойдет ниже, дает картину, близкую к уже рассмотренной для Лангатибейто (рис. 5 В), но с меньшей выраженностью откликов помимо летних текущего года.

В целом на ямальской хронологии по сравнению с гыданской заметно календарное смещение отмеченных реакций прироста кустарников на более ранее время (в пределах месяца): максимумы смещены с июля на июнь-июль, с января-февраля на декабрьянварь и т.д. Отчасти это соответствует известному пространственно-временному смещению климатических волн в Северной Евразии, описанных Н.А. Шполянской (1981, 2010).
Следует отметить, что при расчете множественной регрессии, дающей более высокие значимые показатели детерминации прироста кустарников системой климатических факторов региона ( $\mathrm{R}^{2}$ до 0,8 и более), значимые частные корреляции обычно определяются только для июльских температур, а на Ямале по некоторым метеостанциям также для июньских. Влияние августовских температур на прирост кустарников всегда незначимо, и их частные корреляции близки к нулю. Значимость температур других месяцев при множественной регрессии может проявляться в некоторых сочетаниях месяцев-предикторов, не всегда совпадая с рассмотренными выше показателями парной корреляции. Не выявлена и регрессионная значимость повышенной отрицательной корреляции (до -0,41) прироста кустарников на севере Ямала с количеством осадков в июле (данные м/с Марре-Сале). Нередко значимым компонентом регрессии становится температура декабря предыдущего года, на что указывается и в литературе (Buchwal et al., 2013; Buchwal, 2014).

Из-за небольшой протяженности обеих рассматриваемых ДКХ из крайних северных пунктов региона, слабости автокорреляции 
и возрастных эффектов радиального роста индексирование ширины колец в целом оказалось нецелесообразно для установления дендроклиматических связей и трендов. При увеличении протяженности рядов корреляция с летними и июльскими температурами воздуха индексированных ДКХ увеличивается и приближается к уровню корреляции абсолютных хронологий, что видно на примере 80-летней ДКХ по иве мохнатой с Бованенковского ГКМ (рис. 7, табл. 1). Однако и в этом случае в силу невыраженности возрастных эффектов, слабой автокорреляции $(-0,04)$ и отсутствия возможных искажений математической обработки использование абсолютной ширины колец кустарников дает лучшие результаты.

Для более полной оценки соответствия полученных ДКХ климатической динамике региона рассмотрена возможность объединения полученных нами ДКХ по иве сизой из пункта Лангатибейто, иве мохнатой (19081994) и березе карликовой (1874-1959) с территории Бованенковского ГКМ. В пользу этого свидетельствует отмеченная выше синхронность температурного режима ближайших метеостанций, а также то, что бованенковские ДКХ характеризуются корреляцией 0,87 между собой и 0,7 с ДКХ Лангатибейто. Гыданская хронология из пункта Гольцовое в объединенную не вошла, поскольку находится на значительном удалении от ямальских (400 км) и слабо коррелируется с ними. На промежутке от 1895 до 2011 г. в объединенную хронологию вошло от 13 до 130 радиусов (см. рис. 2).

Три использованные хронологии имеют достаточно продолжительные временные пе-

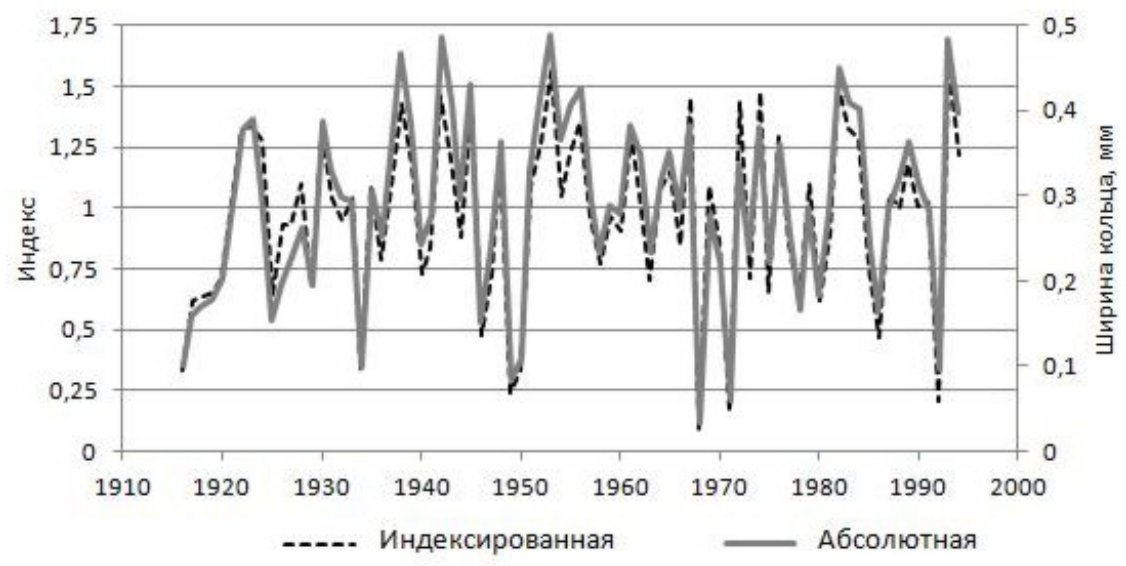

Рис. 7. Абсолютная и индексированная методом отрицательного экспоненциального сглаживания ДКХ ивы мохнатой (Ямал, Бованенковское ГКМ)

Таблица 1. Корреляция абсолютной и индексированной ДКХ ивы мохнатой (Ямал, Бованенковское ГКМ) с температурами воздуха по метеостанциям

\begin{tabular}{|c|c|c|c|c|}
\hline \multirow{2}{*}{ Древесно-кольцевая хронология } & \multicolumn{2}{|c|}{ Салехард } & \multicolumn{2}{|c|}{ Марре-Сале } \\
\hline & Июль & Лето & Июль & Лето \\
\hline Абсолютная ширина колец & 0,62 & 0,66 & 0,68 & 0,74 \\
\hline Отрицательное экспоненциальное сглаживание & 0,56 & 0,55 & 0,56 & 0,58 \\
\hline
\end{tabular}


ресечения, репрезентативные по числу радиусов: на 30-летнем промежутке по иве мохнатой и березе карликовой с территории БГКМ и на 20-летнем по иве мохнатой и иве сизой. По соотношению средней ширины колец разных ДКХ на этих промежутках рассчитаны коэффициенты, позволяющие привести ширину колец ив к ширине колец березы карликовой, нивелировав их видовые и биотопические различия:

$$
\begin{aligned}
& K_{1}=\frac{\bar{w}_{s l}}{\bar{w}_{s g}}=1,3, \\
& K_{2}=\frac{\bar{w}_{s l}}{\bar{w}_{b n}}=2,0,
\end{aligned}
$$

где $\bar{w}_{s l}, \bar{w}_{s g}, \bar{w}_{b n}-$ средняя на данном промежутке ширина колец в обобщенных хронологиях, соответственно, ивы мохнатой, ивы сизой, березы карликовой.

Чтобы привести ширину колец ивы сизой к ширине колец ивы мохнатой, значения каждой индивидуальной хронологии (по 1 радиусу) ивы сизой умножали на $K_{I}=1,3$. Для дальнейшего приведения ширины колец ивы мохнатой к ширине колец березы карликовой значения индивидуальных хронологий ивы мохнатой делили на $K_{2}=2,0$, затем рассчитывали обобщенную ДКХ по всем приведенным к березе карликовой рядам. Полученная таким образом объединенная ДКХ кустарников Северного Ямала (рис. 8) характеризуется корреляцией 0,72 с вековым ходом летних температур воздуха по данным м/с MappeСале и 0,68 по м/с Салехард и отвечает вековому тренду потепления летнего сезона в регионе. Тренд увеличения ширины кольца соответствует уравнению $y=0,0003 x-0,52$, тренд увеличения летней температуры воздуха за тот же вековой период $y=0,0103 x-8,8$, где $x$ - значение календарного года.

Рассчитаны модели множественной регрессии объединенной ДКХ по среднемесячным температурам воздуха текущего и предыдущего годов для разного числа и сочетаний предикторов по м/с Марре-Сале и Салехард, при этом ДКХ разделена на обучающую часть, по которой определялись параметры регрессии, и контрольную, на которой они проверялись (табл. 2, 3, рис. 9).

Все регрессионные модели, начиная от построенной на полном двухгодичном цикле до построенной на двух значимых компонен-

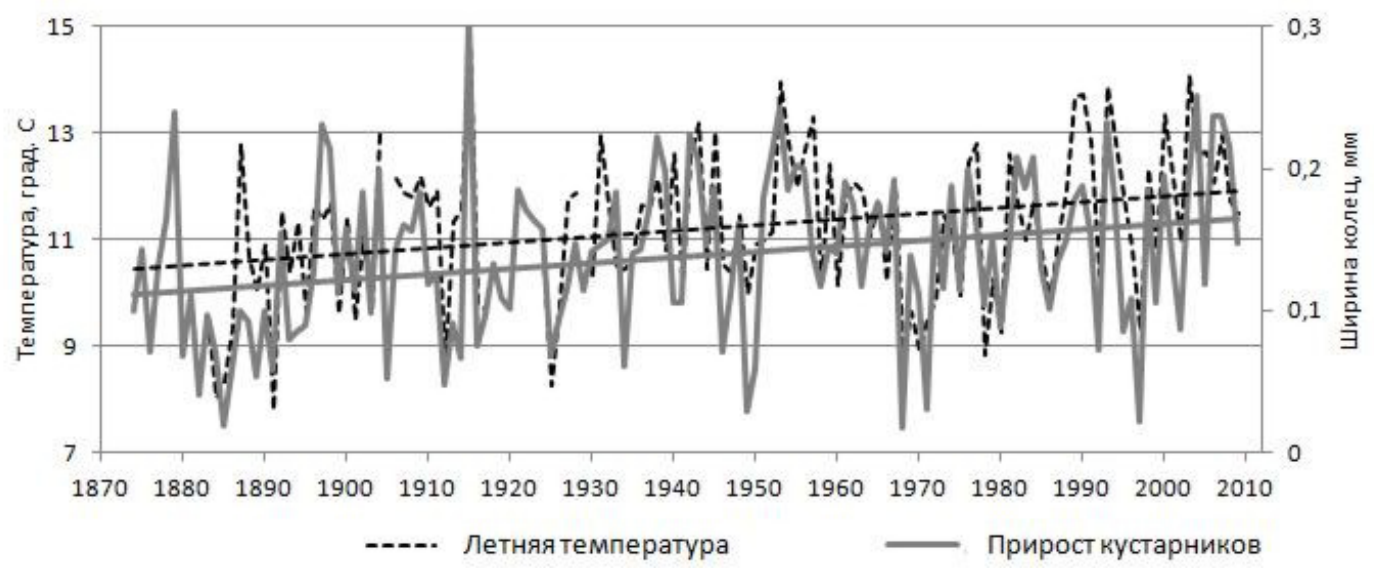

Рис. 8. Объединенная ДКХ кустарников Северного Ямала и ход летних температур воздуха по данным метеостанции Салехард (с линейными трендами) 
Таблица 2. Корреляция фактической ширины колец в объединенной кустарниковой хронологии Северного Ямала и моделей ее множественной регрессии по среднемесячным температурам воздуха текущего и предыдущего (в скобках) года по м/с Марре-Сале

\begin{tabular}{|c|c|c|c|c|c|c|c|c|}
\hline \multirow[b]{2}{*}{ Часть ДКХ } & \multicolumn{8}{|c|}{ Компоненты регрессии (месяцы): значимые компоненты } \\
\hline & $\begin{array}{c}\text { (1)-12: } \\
\text { (3),3,5, } \\
7,12\end{array}$ & $\begin{array}{c}\text { (9)-12: } \\
(12), 3,5 \\
6,7,12\end{array}$ & $\begin{array}{c}\text { (12)-12: } \\
(12), 3 \\
6,7,12\end{array}$ & $\begin{array}{c}\text { (12)-8: } \\
(12), 3 \text {, } \\
5,7\end{array}$ & $\begin{array}{c}\text { 3-8: } \\
3,5,6,7\end{array}$ & $\begin{array}{l}\mathbf{3 , 5 - 7}: \\
3,5,6,7\end{array}$ & $\begin{array}{c}6-8: \\
6,7\end{array}$ & $\begin{array}{c}6-7: \\
6,7\end{array}$ \\
\hline $\begin{array}{l}\text { Обучающая } \\
\text { (1940-1999) }\end{array}$ & 0,91 & 0,87 & 0,86 & 0,83 & 0,77 & 0,78 & 0,74 & 0,74 \\
\hline $\begin{array}{l}\text { Контрольная } \\
(2000-2011)\end{array}$ & 0,78 & 0,81 & 0,87 & 0,79 & 0,83 & 0,84 & 0,91 & 0,90 \\
\hline
\end{tabular}

Таблица 3. Корреляция фактической ширины колец в объединенной кустарниковой хронологии Северного Ямала и расчетных моделей ее множественной регрессии по среднемесячным температурам воздуха текущего и предыдущего (в скобках) года по метеостанции Салехард (во всех моделях значимые компоненты: 6 - июнь, 7 - июль)

\begin{tabular}{|l|c|c|c|c|c|c|c|c|}
\hline \multicolumn{1}{|c|}{ Часть ДКХ } & \multicolumn{7}{|c|}{ Компоненты регрессии (месяцы) } \\
\cline { 2 - 8 } & $\mathbf{( 1 ) - 1 2}$ & $\mathbf{( 1 ) - 8}$ & $\mathbf{( 9 ) - 8}$ & $\mathbf{( 1 2 ) - 8}$ & $\mathbf{3 - 8}$ & $\mathbf{5 - 8}$ & $\mathbf{6 - 8}$ & $\mathbf{6 - 7}$ \\
$\begin{array}{l}\text { Обучающая } \\
(1895-1994)\end{array}$ & 0,83 & 0,82 & 0,81 & 0,80 & 0,79 & 0,79 & 0,78 & 0,78 \\
$\begin{array}{l}\text { Контрольная } \\
(1995-2011)\end{array}$ & 0,80 & 0,80 & 0,80 & 0,76 & 0,75 & 0,80 & 0,77 & 0,77 \\
\hline
\end{tabular}

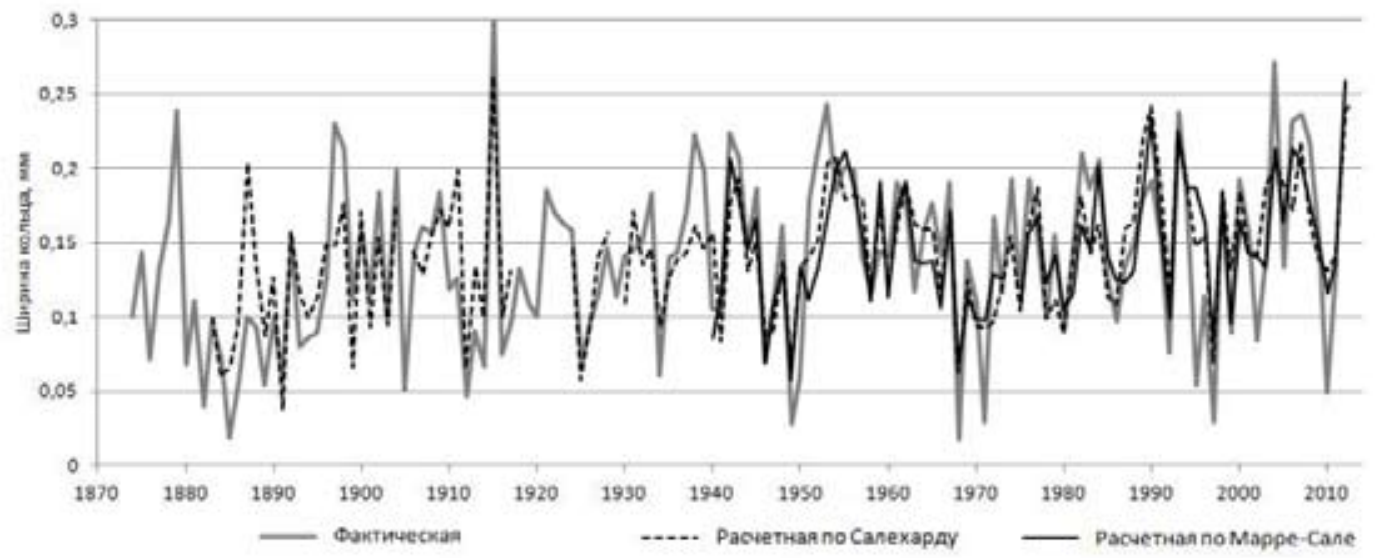

Рис. 9. Объединенная ДКХ кустарников Северного Ямала и ее множественная регрессия по температурам воздуха трех летних месяцев текущего года по данным метеостанций Салехард (обучающая часть хронологии с 1895 по1994 г.) и Марре-Сале (соответственно с 1940 по 1999 г.) 
тах (июнь, июль), показали высокий по всем параметрам значимый $(\mathrm{p}<0,001)$ коэффициент множественной корреляции и высокую корреляцию в контрольной части. Существенного падения достоверности регрессии с ростом числа компонент (в данном случае до 24) не наблюдается. Показательна высокая корреляция ДКХ с регрессионными моделями, построенными на температурах трех месяцев летнего сезона, занимающего второе место после весеннего периода по вкладу в потепление климата региона (контрольный коэффициент корреляции по м/с Марре-Сале 0,91 , по м/с Салехард 0,77). Для данных м/с Салехард значимыми компонентами регрессии во всех моделях были температуры июня и июля, для данных м/с Марре-Сале постоянную значимость имели июльские температуры, реже июньские, кроме них при большом числе предикторов в качестве значимых проявлялись температуры декабря предыдущего года, марта и мая текущего года.

Аналогичную картину потепления климата демонстрируют ДКХ ольхи кустарниковой и ивы мохнатой из низовьев р. Нурмаяха (682' $41^{\prime \prime}$ с. ш., $72^{\circ} 27^{\prime} 10^{\prime \prime}$ в. д.) в 30 км северозападнее мыса Каменного, находящихся у северной границы подзоны кустарниковых тундр (рис. 10). Вековой тренд увеличения ширины колец кустарников, особенно ольхи (1852-2001 гг.), растущей на северном пределе своего распространения, в целом здесь выражен заметно сильнее, но после неблагоприятного 1997 г., когда прирост упал до нуля, он остался на низком уровне из-за ухудшения физиологического состояния ольхи. Реакция
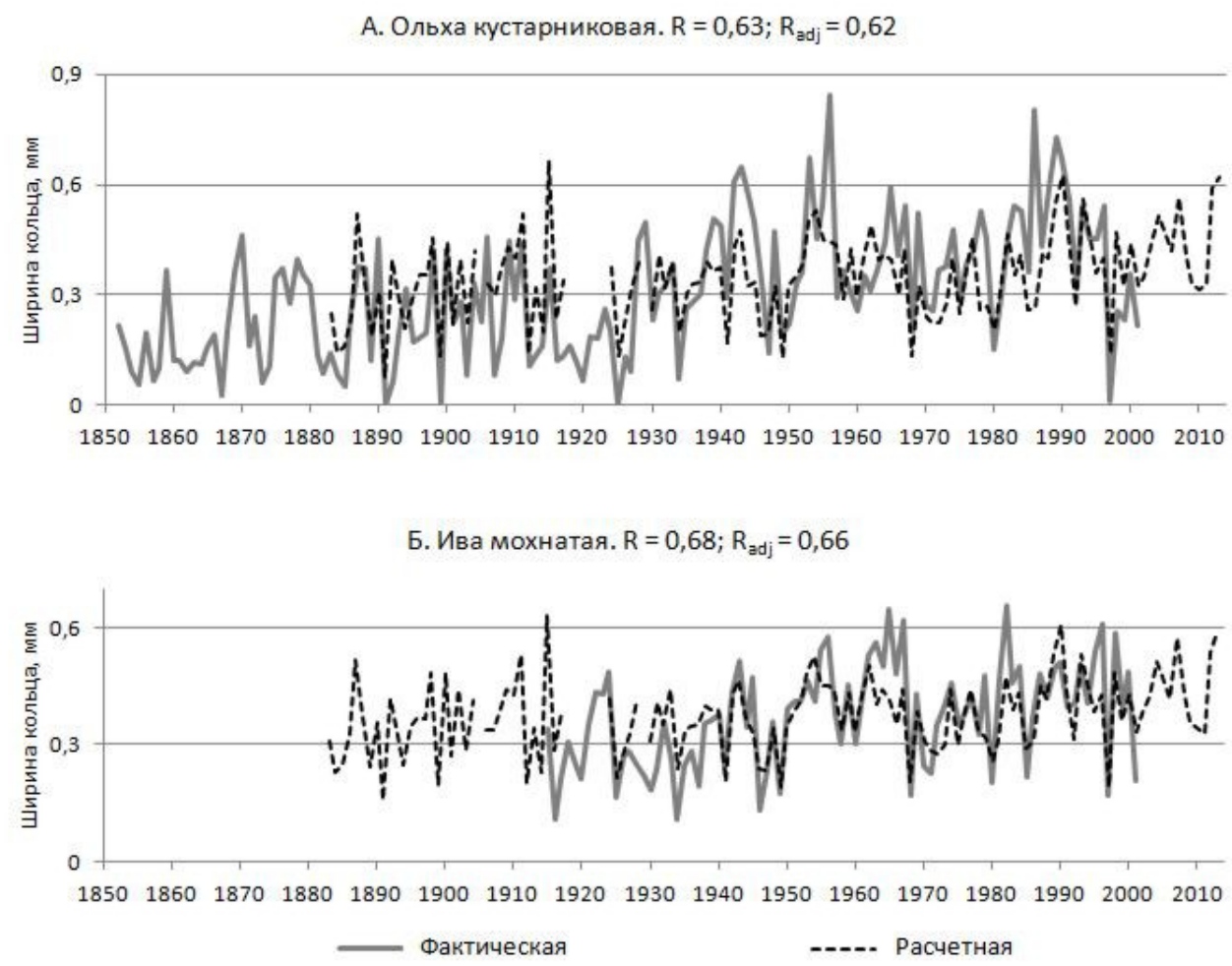

Рис. 10. ДКХ кустарников из низовьев р. Нурмаяха (север подзоны кустарниковых тундр Ямала) и ее множественная регрессия по температурам воздуха трех летних месяцев текущего года по данным метеостанции Салехард 
ивы мохнатой, гораздо шире распространенной на север и лучше адаптированной к его условиям, в 1997 г. была не столь резкой, а дальнейшей физиологической депрессии с уменьшением прироста, не соответствующим приросту, рассчитанному по климатическим данным (м/с Салехард), не наблюдается. Отчасти в силу этого множественная корреляция ДКХ ивы из низовьев Нурмаяхи с температурой трех летних месяцев $(0,68)$ выше, чем у ольхи $(0,63)$, но ниже, чем у кустарников Северного Ямала $(0,78)$. Отмеченные показатели значимы по всем критериям множественной регрессии; значимыми компонентами регрессии, по данным м/с Салехард для ольхи, являются июнь и июль (как и для кустарников Северного Ямала), для ивы мохнатой - июль.
Таким образом, все исследованные ДКХ кустарников Ямало-Гыданского региона, как на северном пределе их распространения, так и на севере подзоны кустарниковых тундр, демонстрируют высокий уровень связи с температурным фактором, особенно (положительный) с летними, прежде всего июльскими, температурами воздуха. Увеличение абсолютной ширины колец соответствует феномену потепления климата, наблюдаемому в регионе в течение последнего столетия. Особенно показательна в этом плане обобщенная хронология кустарников Северного Ямала, включающая характерные для региона их виды и охватывающая период с 1874 по 2011 г.

\section{Список литературы}

Арефьев С.П. (1994) Оценка состояния кустарниковой растительности тундр в районах освоения газоконденсатных месторождений Среднего Ямала. Освоение Севера и проблема рекультивации (Докл. II Междунар. конф.). Сыктывкар, с. 117-122 [Aref’ev S.P. (1994) Assessment of shrubs in the Middle Yamal tundra areas, specialized in development of gas condensate fields. The development of the North and the problem of remediation. Collection of papers of II Intern. Conf. Syktyvkar, p. 117-122 (in Russian)]

Арефьев С.П. (1998) Хронологическая оценка состояния кустарниковых тундр Ямала. Сиб. экол. журн., 3-4: 237-243 [Aref'ev S.P. (1998) The chronological assessment of the shrubs in the Yamal tundra. Siberian Ecological Journal [Sibirskii ekologicheskii zhurnal], 3-4: 237-243 (in Russian)]

Арефьев С.П. (2003) Корреляционный анализ аномальности прироста деревьев и кустарников Тазовского полуострова. Дендрохронология: достижения и перспективы (Материалы Всерос. совещ.). Красноярск, Ин-тут леса им. В.Н. Сукачева СО РАН, с. 51 [Aref'ev S.P. (2003) The correlation analysis of the anomalous growth of trees and shrubs on the Tazovsky Peninsula. Dendrochronology: Achievements and Prospects (Proceedings of all-Russian Meeting). Krasnoyarsk, Institute of Forest named after V.N. Sukachev SB RAS, p. 51 (in Russian)]

Арефьев С.П. (2006) Дендрохронологические исследования и динамика биоты в Тазовской Субарктике. Вестн. экологии, лесоведения и ландшафтоведения, 7: 85-96 [Aref'ev S.P. (2006) Dendrochronological research and dynamics of the biota in the Tazovsky Subarctic area. Bulletin of Ecology, Forest and Landscape Studies [Vestnik ekologii, lesovedeniia I landshaftovedeniia], 7: 85-96 (in Russian)]

Арефьев С.П. (2010) Природно-историческая детерминация биоразнообразия Ямальской Субарктики: древесно-кольцевые хронологии тундровых кустарников. Экологические проблемы северных регионов и пути их развития (Материалы III Всерос. науч. конф. с междунар. уча- 
стием). Ч. 2. Апатиты, Изд-во Кольского НЦ РАН, с. 67-70 [Aref’ev S.P. (2010) Natural-historical determination of biodiversity in the Yamal Subarctic area: tree-ring chronologies of tundra shrubs. Ecological problems of the northern regions and their development (Proceedings of the III all-Russian Scien. Conf. with international participation), Part 2. Apatity, Kolsky Scientific Center RAS, p. 67-70 (in Russian)]

Булыгина О.Н., Коршунова Н.Н., Аристова Л.Н., Трофименко Л.Т. (2010) Исследование климатических условий Ямало-Ненецкого автономного округа и их влияния на развитие нефтегазовой отрасли экономики. Труды Всерос. НИИ гидрометеорологической информации - Мировой центр данныхх. Вып. 175, с. 52-64 [Bulygina O.N., Korshunova N.N., Aristova L.N., Trofimenko L.T. (2010) Study of the climatic conditions of the Yamal-Nenets Autonomous Okrug and their impact on the development of the oil and gas industry. Proceedings of the all-Russian Research Institute of Hydrometeorological Information - World Data Center, 175, p. $52-64$ (in Russian)]

Лейбман М.О., Арчегова И.Б., Горланова Л.А., Кизяков А.И. (2000) Этапы и проявления процесса криогенного оползания по данным исследований на Югорском полуострове и Ямале. Криосфера Земли, 4 (4): 67-75 [Leibman M.O., Archegova I.B., Gorlanova L.A., Koziakov A.I (2000) Stages and manifestations of cryogenic slumping according to research of the Ugra Peninsula and Yamal. Earth Cryosphere [Kristosfera Zemli], 4 (4): $67-75$ (in Russian)]

Николаев А.Н., Самсонова В.В. (2012) Влияние склоновых процессов на произрастание ивы на Ямале. Вестн. ТюмГУ, 12: 195-203 [Nikolaev A.N., Samsonova V.V. (2012) Effect of slope processes on the growth of the willow on the Yamal Peninsula. Bulletin of TSU [Vestnik TumGU], 12: 195-203 (in Russian)]

Природная среда Ямала (1995) Цибульский В.Р., Валеева Э.И., Арефьев С.П., Мельцер Л.И., Московченко Д.В., Гашев С.Н., Брусынина И.Н., Шарапова Т.А. (ред.). В 2 т. Т. 1. Тюмень, Институт проблем освоения Севера СО РАН, 168 с. [Natural Environment of Yamal (1995) Tsybul'ski V.R., Valeeva E.I., Aref'ev S.P., Mel'tser L.I., Moskovchenko D.V., Gashev S.N., Brusynina I.N., Sharapova T.A. (eds). In 2 Vol. Vol. 1. Tyumen, Institute of Northern Development SB RAS, 168 p. (in Russian)]

Природная среда Ямала (2000) Арефьев С.П., Гашев С.Н., Степанова В.Б., Фаттахов Р.Г., Шарапова Т.А., Степанов С.И. (ред.) Т. 3. Тюмень, Изд-во Института проблем освоения Севера CO PAH, 136 c. [Natural Environment of Yamal (2000) Aref'ev S.P., Gashev S.N., Stepanova V.B., Fattakhov R.G., Sharapova T.A., Stepanov S.I. (eds.). Vol. 3. Tyumen, Institute of Northern Development SB RAS, 136 p. (in Russian)]

Растительность Западно-Сибирской равнины. Карта М. 1:1500000 (1976). И.С. Ильина (ред.). М., ГУГК, 4 л. [The vegetation of the West Siberian plain. Map, 1:1500000 (1976), ed. by Il'ina I.S. Moscow, Main Department of Geodesy and Cartography, 4 p.]

Шиятов С.Г. (2009) Динамика древесной и кустарниковой растительности в горах Приполярного Урала под влиянием современных изменений климата. Екатеринбург, Изд-во УрО РАН, 216 c. [Shiiatov S.G. (2009) Dynamics of tree and shrub vegetation in the mountains of the Near-Polar Urals under the influence of contemporary climate changes. Ekaterinburg, UrB RAS, 216 p. (in Russian)]

Шиятов С.Г., Хантемиров Р.М. (2000) Дендрохронологическая датировка древесины кустарников из археологического поселения Ярте VI на полуострове Ямал. Древности Ямала, 1: 
112-120 [Shiiatov S.G., Khantemirov R.M. (2000) Dendrochronological dating of shrubs' wood from archaeological settlement Yarte VI on the Yamal Peninsula. The Yamal Antiquities [Drevnosti Iamala], 1: 112-120 (in Russian)]

Шполянская Н.А. (1981) Мерзлая зона литосферы Западной Сибири и тенденции ее развития. М., Изд-во МГУ, 167 с. [Shpolianskaia N.A. (1981) The frozen zone of the lithosphere of Western Siberia and the tendencies of its development. Moscow State University, 167 p. (in Russian)]

Шполянская Н.А. (2010) Вечная мерзлота и глобальные изменения климата. М.-Ижевск, Ин-т компьютер. исслед., 198 с. [Shpolianskaia N.A. (2010) Permafrost and global climate changes. Moscow-Izhevsk, Institute of Computer Research, 198 p. (in Russian)]

Ямало-Гыданская область (физико-географическая характеристика) (1977) Сиско Р.К. (ред.). Л.: Гидрометеоиздат, 308 с. [Yamal-Gyda area (physical and geographical characteristics) (1977) Ed. by Sisko R.K. Leningrad, Gidrometeoizdat, 308 p. (in Russian)]

Alsos I.G., Eidesen P.B., Broekman R., Loonen M., Rozema J. (2012) No divergence in Cassiope tetragona: persistence of growth response along a latitudinal temperature gradient and under multiyear experimental warming. Annals of Botany, 110: 653-665.

Buchwal A., Rachlewicz G., Fonti P., Cherubini P., Gärtner H. (2013) Temperature modulates intra plant growth of Salix polaris from a high arctic site (Svalbard). Polar Biology, 36 (9): 1305-1318.

Buchwal A. (2014) Dendroclimatological records of annual growth in high and low arctic sites (central Spitsbergen, W. Greenland). Tree ring in archeology, climatology and ecology (TRACE 2014). Aviemore, Scotland, $27 \mathrm{p}$.

Gopalan G. (2000) An interactive image analysis system for dendrochronology. The University of Arizona, 99 p.

Linderholm H.W., Björklund J.A., Seftigen K., Gunnarson B.E., Grudd H., Jeong J.-H., Drobyshev I., Liu Y. (2010) Dendroclimatology in Fennoscandia - from past accomplishments to future potential. Clim. Past. 6: 93-114.

Methods of dendrochronology: Applications in the environmental sciences (1990) Cook E.R., Kairiukstis L.A. (eds.) Dordrecht, Boston, London, Kluwer Acad. Publ., 364 p.

Myers-Smith I.H., Forbes B.C., Wilmking M., Hallinger M., Lantz T., Blok D., Tape K.D., MaciasFauria M., Sass-Klaassen U., L'evesque E., Boudreau S., Ropars P., Hermanutz L., Trant A., Collier L.S., Weijers S., Rozema J., Rayback S.A., Schmidt N.M., Schaepman-Strub G., Wipf S., Rixen Ch., M'enard C.B., Venn S., Goetz S., Andreu-Hayles L., Elmendorf S., Ravolainen V., Welker J., Grogan P., Epstein H.E., Hik D.S. (2011) Shrub expantion in tundra ecosystems: dynamics, impacts and research priorities. Environmental Research Letters, 6 (4): 15p.

Schweingruber F.H., Poschlod P. (2005) Growth rings in herbs and stem anatomy. Forest Snow and Landscape Research, 79 (3): 195-415.

Schweingruber F.H., Rump H.H. (2010) Annual ring studies on plants in permafrost areas of the high Arctic. European Conference on Permafrost, 3: 75.

Rundqvist S., Hedenås H., Sandström A., Emanuelsson U., Eriksson H., Jonasson Ch. and Callaghan T.V. (2011) Tree and shrub expansion over the past 34 years at the tree-line near Abisko, Sweden. Ambio, 40(6): 683-692. 